\title{
Gender-Differentiated Contribution of Goat Farming to Household Income and Food Security in Semi-arid Areas of Msinga, South Africa
}

\author{
S. Tsvuura ${ }^{1}$, M. Mudhara ${ }^{1} \&$ M. Chimonyo ${ }^{1}$ \\ ${ }^{1}$ School of Agricultural, Earth and Environmental Sciences, University of KwaZulu-Natal, Pietermaritzburg, \\ South Africa \\ Correspondence: S. Tsvuura, School of Agricultural, Earth and Environmental Sciences, University of \\ KwaZulu-Natal, P. Bag X01 Scottsville 3209, Pietermaritzburg, South Africa. Tel: 27-72-603-8433. E-mail: \\ tsvuuras@ukzn.ac.za
}

Received: May 15, 2021

Accepted: June 29, 2021

Online Published: August 15, 2021

doi:10.5539/jas.v13n9p73

URL: https://doi.org/10.5539/jas.v13n9p73

The research is financed by Farmer Support Group, University of KwaZulu-Natal, South Africa.

\begin{abstract}
Small-scale goat farming can significantly contribute to livelihoods, particularly in semi-arid areas where rainfall is erratic and crop farming is too risky. The study investigated the gendered-differentiated contribution of goat farming to household food income and food security in the semi-arid area of Msinga in South Africa using focus group discussions, key informant interviews and a questionnaire survey of 241 households. Using the Household Food Insecurity and Access Scale to measure the household food security of goat farming households, descriptive statistics and the Chi-square statistics, results showed a significant relationship between food security and the household socio-economic parameters such as the education level of the household head $(\mathrm{p}<0.05)$, the gender of the household head $(p<0.05)$ and the total household income $(p<0.01)$. The Tobit regression model showed that the main factors determining food security at the household level were education levels, gender and the total household income. Female-headed households were less food secure than male-headed households because they did not have reliable employment to provide adequate and nutritious food for their households. Therefore, empowering women is crucial to ensuring food security because unstable employment opportunities lead to households' failure to cope with food insecurity adequately. Goat farming did not contribute to household food security because it generated little income as goat sales were generally low, with a mean of 2.1 for male headed-households and 1.0 for female headed-households in 12 months $(\mathrm{p}<0.05)$. Farmers obtained little income from goat farming because goat flock sizes for most households did not increase due to poor nutrition, diseases, predation, and theft. With the household food basket cost reported to be ZAR3 400/US\$188, a household would need to sell up to four goats each month to survive solely on goat farming. However, where goat flock size was small, households limited goat sales to maintain the potential to increase their flock size. Empowering women by promoting rural education may increase their chances of being exposed to better management options, acquiring a better understanding of goat management practices, and making informed decisions, thereby contributing to the improvement of food security. Enhancing goat production is essential to increase flock sizes, as this enables farmers to make more sales, thereby improving food security. Therefore, extension workers need to help farmers better manage and utilize goat farming to their full potential. Finally, rural households need to reduce their autonomy and dependency on supermarket goods and become more agri-oriented.
\end{abstract}

Keywords: gender, determinants, food security, Tobit regression model

\section{Introduction}

\subsection{Background}

Small-scale goat farming in most communal areas is a major source of livelihoods that can eradicate poverty and contribute to sustainable food security (Ngambi et al., 2013; Dube, 2015). Several studies have focused on the importance of goats for diversifying the income sources of the rural poor (Njuki \& Sanginga, 2013; Aldosari, 2017). However, not many studies have taken a gendered analysis of the factors affecting goat management decisions such as the role and potential of goats to improve income and food security in semi-arid areas. 
Understanding the opportunities and challenges that farmers face through gendered lenses can enhance the benefits of goat production. It is important to consider gender because women have been pivotal to attaining food security in rural households. A better understanding of the mechanisms through which they make their contribution is required. A gender-disaggregated analysis of the decision-making processes and goat farming's contribution towards household food security is necessary.

Food security exists when all people have physical, social, and economic access to sufficient, safe, and nutritious food, which meets their dietary needs and food preferences for a healthy life (FAO, 2008). The dimensions of availability, stability, access and utilization ensure food security within households. Food security can be u a measure of household welfare because its absence is related to both the cause and effect of poverty in households (FAO, 1996).

The achievement of food security at the household level is through the interaction of a complex set of factors, which vary across households. Gender is one of these key determinants of food security. Nonetheless, even gender itself is multi-dimensional and complex in its attributes and nature. The attainment of food security is central to the Sustainable Development Goals (SDGs) as SDG 2 talks explicitly about eradicating hunger. In line with human rights, several governments include food security as central to their national objectives. Indeed, South Africa's contribution identifies the achievement of food security as one of the basic human rights of its nationals. Abdullaha et al. (2017) revealed that age, gender, education, remittances, unemployment, inflation, assets, and disease incidence are the factors that determine household food insecurity. De Cock et al. (2013) revealed that the main determinants of household food security in the Limpopo Province of South Africa were human capital (education, household size and dependency ratio) and household income, with income being one of the most significant determinants (Lê, 2015). In their studies, Mango et al. (2014) found age and education level of household head, household labour size, livestock ownership, remittances and access to market information to influence household food security positively. However, these determinants of food security may differ depending on social norms of an area or at the household level because of the multi-dimensional phenomenon of food security. Oyekale (2013) highlighted that large household sizes could increase agricultural production due to labor provision, but where production resources are limited, large household sizes can lead to food shortages. Schwabe (2004) indicated that large households with many dependents are likely to be poor because they require significant income to keep household members out of poverty, and higher dependency ratios are more frequent among the poor.

Deciphering the complexities of the gender and food security link helps understand how to increase household food security. Inequalities in women's access to assets such as land and livestock and other livelihood opportunities make them vulnerable to malnutrition and food insecurity. Although government social grants may assist women in caring and looking after households, they do not transform gender relations (Patel and Hochfeld, 2011). They do not stimulate women's participation in developmental activities (Patel et al., 2015). With fewer assets and heavier burdens associated with additional household obligations, women are more vulnerable to shocks of household food insecurity. In the livestock sector, goats are often the only asset possessed by resource-poor households whose ownership is easily accessible to women. They are easier to handle than dairy cattle because they require low amounts of food and can reproduce at a young age with multiple births (Rahman et al., 2016). There is remarkedly low capital required to invest in goat production, yet there is high meat productivity and other products (García-Winder \& Chavarría, 2017). Literature has highlighted what several studies have attributed to the importance of goats in diversifying the income of the rural poor (Njuki \& Sanginga, 2013; Aldosari, 2017; García-Winder \& Chavarría, 2017). Henceforth, if sustained, goat production and productivity can help deal with food security challenges and alleviate poverty.

Although women and children are often responsible for the provision of labour in many goat-related activities (Hulela, 2010), they often own fewer goats than men. They are less involved in decision-making (Webb \& Mamabolo, 2004), which emanates from the cultural settings which are biased against women (Chukwuka et al., 2010). As a result, even though several studies have reviewed aspects of women and food security, this has failed to translate into the expected outcomes in addressing food insecurity in much of Southern Africa (Olowu, 2013). Obtaining financial independence will increase women's bargaining power and enhance their rights to participate in decision-making and increase household food security.

\subsection{Linking Gender to Food Security}

The thinking of food security has gradually moved from global and national food supply concerns to households' access to food. This shift brings in the argument of gender, emphasizing which gender should drive household food security (Watuleke, 2014). Gender is considered an essential socio-economic factor when investigating the roles and restrictions of people involved in agriculture (Deere et al., 2012). Some findings have suggested that 
food security interventions can improve gender equality and food security (FAO, 2017). Although several studies have reviewed aspects of gender and food security, there has been a failure in addressing food insecurity (Olowu, 2013), thereby reflecting the complexity of the relationship between the two. The inability to produce results has been mainly due to the failure in understanding the fundamental issues of gender dynamics in decision-making, asset ownership, and income control.

Food insecurity disproportionately affects women and girls mainly due to cultural restrictions on access to education, assets and land. Households and society may restrict women's decision-making power over household income (Brody, 2015; FAO, 2015b). Even though more women than men are dependent on farming in Africa, gender inequalities continue (FAO, 2017).

Studies found that gender equality programmes aimed at empowering women by increasing their bargaining power within households were associated with health, food, and education improvements, particularly of girls (FAO/ADB, 2013; Brody, 2015). Improving gender equality positively affects food security, mostly in children. Household allocation of resources and decision-making favoring women improve food security (FAO, 2017). Duflo (2003) indicated that women's old-age pensions led to a considerable increase in childhood development. Improved gender equality enhances food security outcomes (FAO, 2017), so gender-targeted inventions should improve food security as women are interested in investing in household consumption needs. Women's rights to land, control over assets and livelihood opportunities should be equal to men's as this positively affects food security (Doss et al., 2017).

In many rural areas, women rely on subsistence agriculture, but their most significant constraint is land tenure (Selepe et al., 2015). Cultural laws deny women the same rights to property as men, and female-headed households often face challenges in ensuring food security for their households because of lack of security of land tenure and access to loans due to lack of collateral (Olowu, 2013). In addition, culture lead to women having less personal autonomy, fewer resources and limited influence over household decision-making processes (Selepe et al., 2015). Although there may be no constitutional barriers to gender equality, the laws that govern inheritance and marriage are often the cause of discrimination against women. Local authorities and traditional councils tend to have limited gender equality factors through the land tenure system, which discriminates against women (Babajide, 2015). Hence, crop production generally favours men because of their land ownership (Olowu, 2013).

Bahta et al. (2017) indicated that livestock farming, unlike crop production, may not contribute to gender inequality because both genders may have equal access and right of ownership to livestock and can be involved in the production, unlike cropping allocated by households and not by gender. Livestock farming may be an important sector towards developing and improving rural livelihoods and alleviating poverty, especially among the poor. Exploring women's and men's perspectives on livestock, particularly goats, is crucial in alleviating food insecurity (Desta et al., 2017).

\subsection{Conceptual Framework}

Most rural dwellers in South Africa depend on social grants. The government gives social grants to the country's citizens monthly to improve their living standards. The recipients include elderly people, people with disabilities and those with young children. The need for social grants, particularly in rural areas, is due to the lack of economic activities and also that rural people often lack the necessary skills to take advantage of economic opportunities, which may improve their living conditions (Adams-Kane \& Lim, 2016). Most women access social grants as they are caregivers of children (Patel, 2012). According to the 'development as freedom' theory (Sen, 1999); although social grants have a positive role to play in most households of reducing poverty, they are inadequate to entirely end poverty (Selepe et al., 2015; Mokwena, 2016; Devereux \& Waidler, 2017). Social grants are viewed as safety nets to prevent absolute poverty in households but are inadequate to meet all household needs. Trefry et al. (2014) found that social grants are a disincentive to farming and gardening. Another concern is that social grants can end up buying non-essentials such as alcohol and drugs. In some households, the grant is the sole income source that the entire household shares (Mokwena, 2016). Therefore, households need to diversify livelihoods to other on-farm and off-farm activities (Barret et al., 2001; Mathebula et al., 2017), reducing social grant dependency.

Amartya Sen's theory of freedom of development gave rise to the capability approach (Sen, 1999). According to the capability approach, humans differ in converting means into opportunities or outcomes or transforming a resource into opportunities. It relies on the view that the development of human skills is needed for poverty alleviation as it gives people freedom through the development of their capabilities. Although health, adequate nutrition and freedom of speech are important capabilities, human capital development, such as education, is one 
of the most effective tools for poverty alleviation (Nussbaum, 2011). Knowledge increases the ability of rural households to explore technological innovations and market opportunities. There is a correlation between poverty and low education level and unemployment (Baiyegunhi \& Fraser, 2010). Gubbles (2013) noted that increasing education levels, particularly female literacy, is important as it increases family incomes and leads to better nutrition. Hence, it is linked directly to increased food and nutritional security.

Household food security requires enough food supply to meet specific dietary needs, either through production, purchase, or gifts (Banwat et al., 2012). Poverty leads to households consuming diets that lack diversity and may lead to micronutrient deficiencies. It may also lead to households consuming lower quality and less nutritious foods, reduction in the quantity of consumption by certain members of the household, a decrease in the frequency of consumption and or size of the portion, and in malnutrition, especially in children (Brinkman et al., 2010). Baiphethi and Jacobs (2009) alluded that incidences of food insecurity are high in South Africa due to increased dependence on market-purchased food. Food purchases require households to have cash. However, given the prevailing high levels of unemployment, particularly in rural areas, the income to purchase food is often scarce. Therefore, relying on cash to buy food makes households vulnerable to food insecurity (Manyamba et al., 2012). Manyamba et al. (2012) thus referred to food insecurity as not a failure to produce food at a national level but as a failure by households to have adequate income to buy food.

Although women play an important role in providing food for their households, social and cultural inequalities make them have little access to productive resources, markets, education and household decision-making power (Olowu, 2013; Trefry et al., 2014; Sharaunga et al., 2015). Baiyegunhi and Fraser (2014) observed a positive relationship between being a female-headed household and poverty. Female-headed households are more likely to be inferior compared to male-headed ones. Felker-Kantor and Wood (2012), Kassie et al. (2014) and Zakari et al. (2014) explored the link between the gender of a household head and food security. They found that female-headed households were less food secure than male-headed ones. However, Ibnouf (2011) showed that women contribute more to food security than men. Most men migrate seasonally or even permanently due to unfavourable climatic conditions and conflicts, leaving women to play a significant role in producing and providing food for their households.

Ansah et al. (2019) argued the importance of resilience (socio-economic systems' capacity to withstand shocks) to household food security. A household's resilience derives from assets, income, and opportunities such as social safety nets and access to public services such as government social grants. A conceptual model by Vaitla et al. (2012) linked household assets to income; that assets can be employed to generate income for household consumption.

Assets and Income

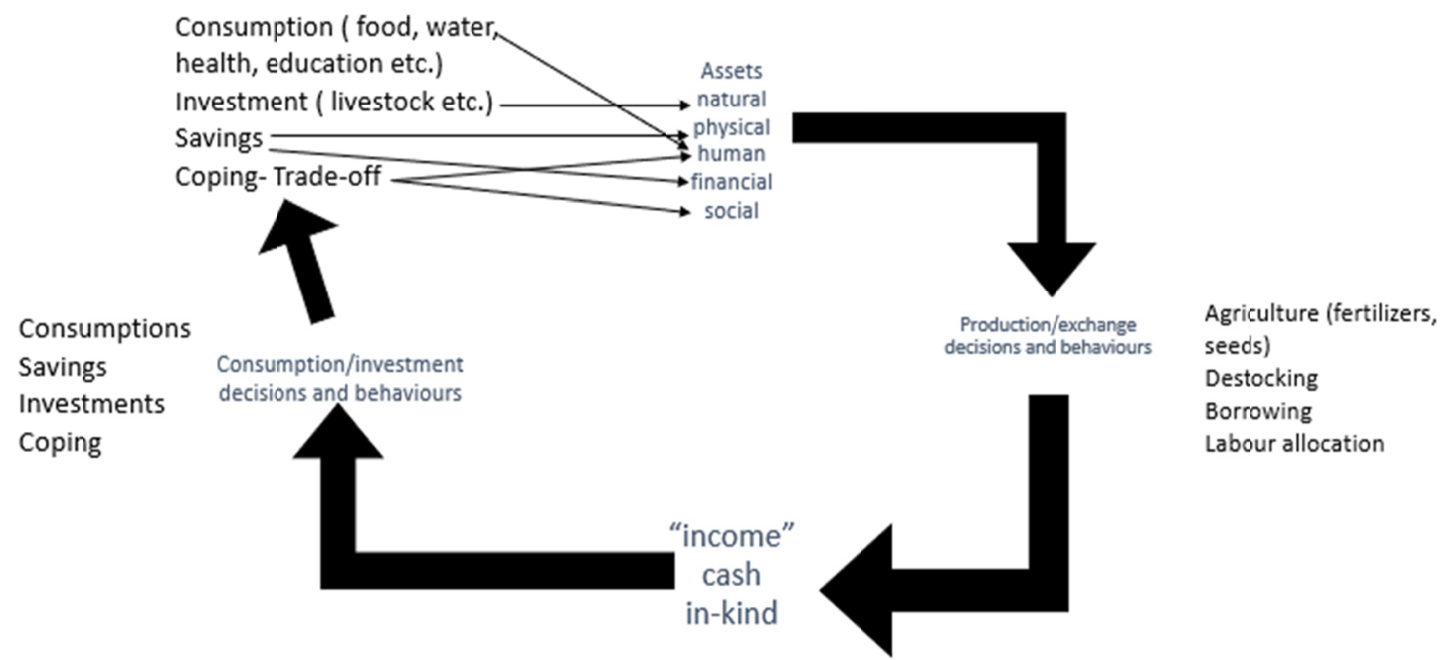

Figure 1. Livelihood cycle framework. Adapted from Vaitla et al. (2012)

In the conceptual model, Vaitla et al. (2012) refer to assets such as agriculture or livestock-based as livelihood strategies that achieve outcomes such as food security, nutritional status or health. The conceptual framework 
begins with assets since they can be used in different strategies to produce income. It then considers whether the income obtained gets consumed, saved, or invested since these shape the asset portfolio that the household holds in the following cycle.

In line with the conceptual model by Vaitla et al. (2012), the study's objective, therefore, was to investigate the gender-differentiated contribution of goat farming to food security in semi-arid areas. Semi-arid areas have considerable potential for goat production due to suitable rangelands. However, despite the abundance of goat numbers and rangelands, most rural communities in semi-arid areas experience poverty and malnutrition. The study hypothesized that addressing food insecurity requires assets such as goats that can be living savings and converted into cash to buy food for the household whenever needed (Bettencourt et al., 2015). The study investigated the gender-differentiated contribution of goat farming to food security. A better understanding of gender and assets in food security is essential as women's ownership and control of assets are often associated with poverty reduction at the household level (Johnson et al., 2016).

\section{Methods}

\subsection{Study Site}

The study site of Msinga Municipality $\left(28^{\circ} 10^{\prime} \mathrm{S} 30^{\circ} 15^{\prime} \mathrm{E}\right)$ was selected because it produces indigenous goats. Msinga Local Municipality, found in the uMzinyathi District Municipality in KwaZulu-Natal, South Africa (Tapela, 2011), comprises six traditional authority areas (Dearlove, 2007).

Msinga has a population 190 000, with two out of five of the population being under 15 years (StatsSA, 2016). About $57 \%$ of the population are women. It is one of the poorest municipalities in the district due to limited economic resources and activities. As a result, approximately $90 \%$ of its population depends on government social grants and male household members are forced to leave the municipality searching for employment in cities (Msinga Municipality IDP, 2014).

Msinga is a semi-arid area that receives erratic rainfall patterns with an average of $600 \mathrm{~mm}$ annually and ranges between 350 and $900 \mathrm{~mm}$. The summer temperatures can be very high, reaching up to $44^{\circ} \mathrm{C}$. The unpredictable rainfall and rocky landscape make it risky to invest in crop production in the area (Cousins, 2012), yet goats thrive well in this environment.

\subsection{Sampling and Selection of Households}

Sample selection had four stages, with purposive sampling being the first stage. The selection of the traditional authority areas of Mthembu and Mchunu was purposive because of the different socio-economic opportunities in the two areas. Many households in Mthembu traditional authority obtain income from the Tugela Ferry Irrigation Scheme plots, which contrasts with Mchunu traditional authority. Several households in Mthembu have access to or work in irrigation scheme plots, and it is mostly women involved in these garden projects. Apart from government grants, households' income in the Mthembu area also comes from the sale of garden produce. This source of income influences their perception on the role of goats and as a result, goat sales tend to be lower than those from Mchunu traditional area. Mthembu is the only traditional area in Msinga with access to Tugela River and uses the irrigation scheme plots.

The number of households that owned goats in these two tribal authorities was 2148 (GAP KZN, 2017). Raosoft's (2004) sample size calculator was used to calculate the sample size (with a 90\% confidence level) of the study area, giving a sample size of 241 households. Subsequently, stratified sampling was conducted, which divided the population into two strata (each stratum representing a traditional area). The size of each traditional area influenced the proportion of the sample contributed to the sample. The sample sizes for Mthembu and Mchunu were 128 and 113 households, respectively. Traditional authority areas have several dip tanks based on livestock ownership. Dip tank administrators keep cattle and goat statistics and issue farmers with permits to sell livestock when needed. Households pay annual contributions to their dip tank managers for membership and access to services. Three dip tanks randomly selected in each traditional authority area participated in the survey. Finally, households were selected randomly at each dip tank level.

\subsection{Data Collection}

Data were collected between May and June 2019 using a structured household questionnaire, focus group discussions (FGDs), and key informant interviews. The FGDs and key informant interviews generated data that augmented the structured questionnaire by explaining the quantitative data. Key informants consisted of an equivalent number of males and females: male and female Community Animal Health Workers (CAHWs), a male extension officer, a female Non-Governmental Organisation (NGO) representative, a female social worker and a male dip tank manager. In addition, four FGDs were conducted, one consisting only of males and the other of 
women, from each respective traditional authority area. Each group had 12 participants, two representing a particular dip-tank area. Female participants included the married, single and widowed. The FGDs helped to understand the factors affecting the sale of goats, the type of goats sold, and goat marketing options in the area.

The questionnaire was pre-tested and administered by six isiZulu-speaking enumerators. During the questionnaire survey, one person per household responded to questions while noting the gender of the household head to categorize them as male-headed households (MHHs) and female-headed households (FHHs). During questionnaire surveys, female-headed households were categorized as such because they had no adult male member in the household as these were single or widowed women, while married men and married women belonged to male-headed households.

Key informant interviews aimed to understand the household food security situation in the area and the contribution of goats to household income. In the study, a household consisted of people who ate together and shared income and expenditures.

The study determined demographic and socio-economic variables such as age, gender and education level of household head, household size, ownership of land and livestock, food, respondent's perception of their food security status, and income source. In addition, information relating to household composition, food consumption, food production, household income, and access to resources was collected. The analysis showed how much income households obtained and determinants of goats' contribution to household income. The questionnaire measured household food security using the Household Food Insecurity and Access Scale (HFIAS) indicator (Daniel et al., 2013). This measurement of HFIAS aimed to find an association between household food security and socio-economic parameters such as gender, marital status, household income, household size, household heads' education levels and occupation, land ownership, number of assets such as goats, and food stored. Focused group discussions also investigated the cultural and community views about goats and how they contribute to household food security and livelihood patterns in the area. Data collection observed all ethical considerations based on the ethical clearance that the University of KwaZulu-Natal granted.

\subsection{Statistical Analyses}

Statistical analyses used different tools run on SPSS (2019). The tools included descriptive statistics and chi-square tests (Crosstabs). The Tobit regression model was used to estimate the determinants of food security. Qualitative data from the focus group discussions and key informants explained the content and concepts obtained from the questionnaire survey questions. The analysis emphasized the experiences and views of the participants.

Descriptive analysis of all the variables was conducted by studying the frequencies of the variables to examine the selected households' socio-economic characteristics. Chi-square tests determined the association between categorical variables such as food security and different socio-economic parameters (such as gender, education level and marital status of the head of household, total household size, land ownership, location, total household income, source of regular food, number of meals eaten per day, occupation of household head and number of goats owned).

Food security was measured using the HFIAS. Although other indicators measure food security, such as the Household Dietary Diversity Scale (HDDS), which captures food quality and diversity, this study focused on food quantity eaten or sufficiency, which is what the HFIAS captures (Daniel et al., 2013).

The HFIAS was used to assess the food security status of households. Nine questions probed whether the household experienced one form of insufficient access to food in the past 30 days and, if yes, with what frequency (Pérez-Escamilla et al., 2017; De Cock et al., 2013). Households had three possible responses to each of the nine questions, ranging from zero to 27; the higher the score, the greater the food (access) insecurity the household experienced (De Cock et al., 2013). Therefore, in the study, food secure households had lower HFIAS scores, while food insecure households had higher HFIAS scores.

Each question's frequency of experience created a continuous variable that became the HFIAS score (Swindale $\&$ Bilinsky, 2006). The dependent variable was household food security, grouped into four ordered categories that had cut-off points on the scale, which enabled categorical classification of whether households were food secure or not depending on their socio-economic condition. The categories were 1 (food secure: household experiences none of the food insecurity conditions, or just experiences worry, but rarely), 2 (mildly food insecure: household worries about not having enough food sometimes or often, and/or is unable to eat preferred foods, and/or eat monotonous diet than desired and/or some foods considered undesirable, but only rarely), 3 (moderately food insecure: household sacrifices quality more frequently, by eating monotonous diet or 
undesirable foods sometimes or often, and/or has started to cut back on quantity by reducing the size of meals or number of meals, rarely or sometimes) and 4 (severely food insecure: household cuts back on meal size or the number of meals often, and rarely or frequently runs out of food, goes to bed hungry or whole day without eating). Classification for the four HFIAS categories followed Coates et al. (2007). The chi-square statistic determined whether there was an association between these four food security categories and household socio-economic parameters.

The Tobit regression model was used with the HFIAS score as the dependent variable to analyse food security determinants. The dependent variable was lower and upper censored at zero and 27, respectively. The Tobit model is appropriate for analysing lower and upper censored variables (McDonald \& Moffitt, 1980). The Tobit model describes the relationship between a censored continuous dependent variable and a vector of independent variables (Durlauf \& Blume, 2010). The variables explaining whether or not the observed dependent variable is censored also explain the variable's level when it takes positive values (Cunillera, 2014). Households considered food secure had lower HFIAS scores, while that considered food insecure had higher HFIAS scores. Computing in STATA Version 15 software produced the model. The Tobit is a particular case of a censored regression model because the latent variable $Y_{i}$ cannot always be observed while the independent variable $X_{i}$ is observable. A common variation of the Tobit model is censoring at a value $y_{\mathrm{L}}$ different from zero.

The empirical model for quantifying the determinants of HFIAS was given as:

$$
Y_{i *}=\beta_{0}+\beta X_{i}+e_{i}
$$

where, $Y_{i^{*}}=$ is the latent variable of the dependent variable (HFIAS); $\beta=$ vector of parameters to be estimated; $X_{i}=$ set of explanatory variables (Table 1$) ; e_{i}=$ the disturbance term.

The model errors $e_{i}$ are assumed to be independent, $\mathrm{N}\left(0, \sigma^{2}\right)$ distributed, conditional on the $X_{i}$. The observed $Y_{i^{*}}$ is defined as 1 if $Y_{i^{*}}>0$ and 0 if $Y_{i^{*}} \leq 0$.

\subsubsection{Independent Variables Used in the Tobit Model}

The independent variables were household characteristics such as gender, education level of household head, location, household head, sale of goats in the past 12 months, saving money, food storage that lasts for a month, number of goats per household and the total household income. Table 1 gives the variables used in the model and their expected effect on the dependent variable (food security).

Table 1. Description of independent variables used in the Tobit model

\begin{tabular}{|c|c|c|c|}
\hline Variables & Measures & Expected effect & Rationale \\
\hline Gender & $\begin{array}{l}1=\text { Male headed household, } \\
0=\text { Female-headed household }\end{array}$ & + & $\begin{array}{l}\text { Male-headed households tend to be food secure as men } \\
\text { usually own the means of production }\end{array}$ \\
\hline $\begin{array}{l}\text { Goats sold in past } \\
12 \text { months }\end{array}$ & $1=$ Sold, $0=$ Did not sell & + & $\begin{array}{l}\text { Households that sold goats had income to buy food items, and } \\
\text { therefore more food secure }\end{array}$ \\
\hline Save money & $1=$ Yes, $0=$ No & + & Money saved can be used to cope with food shortages \\
\hline Food stored for a month & $1=$ Yes, $0=$ No & + & $\begin{array}{l}\text { Food stored to alleviate future shocks, such as an increase in } \\
\text { food prices. Those who store food are likely to be food secure }\end{array}$ \\
\hline Educational level & Years of schooling & - & $\begin{array}{l}\text { Households with an educated head are more likely to be food } \\
\text { secure since they can have access to opportunities. }\end{array}$ \\
\hline Total household income & ZAR & - & The more the income, the more food a household can buy \\
\hline Goat flock sizes & Numbers & - & $\begin{array}{l}\text { Higher goat ownership is potential income. Goats can sustain } \\
\text { consumption and achieve food security when sold }\end{array}$ \\
\hline Age of household head & $1=$ young, $0=$ old aged & + & $\begin{array}{l}\text { Household heads younger in age can fend for themselves and } \\
\text { be more food secure }\end{array}$ \\
\hline Location & $\begin{array}{l}1=\text { Mthembu traditional authority area, } \\
0=\text { Mchunu traditional authority area }\end{array}$ & - & $\begin{array}{l}\text { Mthembu area has access to irrigation to sustain gardens will } \\
\text { be more food secure than Mchunu, which does not have }\end{array}$ \\
\hline
\end{tabular}

The logic behind the gender having a positive sign is that male-headed households were expected to be more food secure than female-headed households. Males often earn more income than females because of socio-cultural factors that prohibit women from participating in the labour force (Mallick \& Rafi, 2010). In addition, lack of access to production resources also limits women's contribution to household income (Muhoyi et al., 2014). Faridi and Wadood (2010), Nyako (2013), and Muche et al. (2014) stated that education levels are directly related to food security. Households become more food secure with increasing education levels of the 
household head. Therefore, the education levels of household heads had a negative sign, indicating that the educated household heads are expected to be more food secure than those with fewer years of schooling. Hoddinot and Yohannes (2002) indicated that higher educational attainment by heads of households is likely to be associated with higher incomes. Higher household income links with more food expenditure.

Households that saved money to cope with food shortages were expected to be more food secure than those which did not save money (Shariff \& Khor, 2008), hence the positive sign. Thamaga-Chitja et al. (2004) stated that effective food storage plays a significant role in making food supply stable at the household level. Extended food storage minimises expenses incurred when regularly buying food and enduring price increases and increased transport costs. Food storage had a positive sign indicating that households that store food are expected to be more food secure than those which do not. Rose (2008) noted that the more assets a household owns, the better it will face difficult situations in the future. Hassen and Tesfaye (2014) reported that income from goats could contribute to household nutrition. Byaruhanga et al. (2014) also showed that households with relatively larger flock sizes sold more goats than those with smaller flocks resulting in more income to use for household expenses. Therefore, goat flock sizes had a negative sign as those with larger goat flocks were expected to be more food secure.

Baiyegunhi and Fraser (2010) reported that households headed by old age people tend to be more vulnerable because they cannot fend for themselves due to their old age. Therefore, young household heads can fend for themselves and be more food secure, and the variable had a positive sign. Shisanya and Hendriks (2011) mentioned that home gardens positively influence food insecurity by decreasing micro-nutrient deficiencies. The location had a negative sign as Mthembu households were more likely to be food secure because most of them own gardens, compared to those in the Mchunu area.

\section{Results}

\subsection{Descriptive Statistics and Socio-economic Characteristics of Households}

Table 2 shows descriptive statistics for household socio-economic characteristics. Most of the households were male-headed. The heads belonged to the adult age group (66.8\%), were married (55.6\%), and only had up to primary school education level $(41.5 \%)$. The traditional authority owned most of the allocated land $(97.1 \%)$. The most prevalent occupation was temporary $(26.1 \%)$ or permanent employment $(21.6 \%)$, while some were old-age pensioners (16.6\%). Although most households did not save money $(66.8 \%)$, they could store food for at least a month $(61 \%)$. Most households did not grow any crops, so they relied on supermarkets $(50.6 \%)$. Coping strategies for household emergencies included selling livestock (35.7\%) or borrowing money from relatives and friends $(27.8 \%)$. 
Table 2. Descriptive statistics for socio-economic characteristics of households

\begin{tabular}{|c|c|c|c|}
\hline Variable & Categorical & Frequency & Percentage \\
\hline \multirow{2}{*}{ Location (household population) } & Mchunu & 118 & 49 \\
\hline & Mthembu & 123 & 51 \\
\hline \multirow{2}{*}{ Gender } & Male & 165 & 68.5 \\
\hline & Female & 76 & 31.5 \\
\hline \multirow{3}{*}{ Head of household age } & Youth & 17 & 7.1 \\
\hline & Adult & 161 & 66.8 \\
\hline & Old age & 63 & 26.1 \\
\hline \multirow{4}{*}{ Marital status } & Single & 11 & 4.6 \\
\hline & Married & 134 & 55.6 \\
\hline & Widowed & 62 & 25.7 \\
\hline & Cohabiting & 34 & 14.1 \\
\hline \multirow{4}{*}{ Education level } & None & 63 & 26.1 \\
\hline & Primary & 100 & 41.5 \\
\hline & Secondary & 63 & 26.1 \\
\hline & Tertiary & 15 & 6.2 \\
\hline \multirow{2}{*}{ Goat ownership (mean per household) } & Mchunu & 21 & 45 \\
\hline & Mthembu & 26 & 55 \\
\hline \multirow{7}{*}{ Head occupation } & Buying \& selling & 30 & 12.4 \\
\hline & Farming & 12 & 5.0 \\
\hline & Permanent job & 52 & 21.6 \\
\hline & Temporary job & 63 & 26.1 \\
\hline & Unemployed & 32 & 13.3 \\
\hline & Self employed & 12 & 5.0 \\
\hline & Old age pension & 40 & 16.6 \\
\hline \multirow{2}{*}{ Save money } & No & 161 & 66.8 \\
\hline & Yes & 80 & 33.2 \\
\hline \multirow{2}{*}{ Source of regular meal } & Supermarkets & 122 & 50.6 \\
\hline & Own production \& supermarkets & 119 & 49.4 \\
\hline \multirow{5}{*}{ Coping strategy } & Sell livestock & 86 & 35.7 \\
\hline & Sell other assets & 2 & 0.8 \\
\hline & Use cash savings & 38 & 15.8 \\
\hline & Borrow & 67 & 27.8 \\
\hline & Reduce spending & 48 & 19.9 \\
\hline \multirow{2}{*}{ Receive remittances } & No & 131 & 54.4 \\
\hline & Yes & 110 & 45.5 \\
\hline \multirow{2}{*}{ Food storage for a month } & No & 94 & 39 \\
\hline & Yes & 147 & 61 \\
\hline
\end{tabular}

\subsection{Household Food Production}

Although female-headed households were either married, single, widowed, or cohabiting, results showed that $82 \%$ of these female heads were widowed. Generally, if the husband is alive, he tends to be the household head. All the female-headed households made one category because of the small proportion that was either single, married, or cohabiting (18\%). The results only showed male-headed households compared with female-headed households without the different categories of female heads.

A few households (39\%) in Mchunu traditional authority had gardens due to lack of water when compared to Mthembu traditional authority $(73 \%)(\mathrm{p}<0.01)$ (Table 3). Residents of Mthembu traditional authority were involved in gardening due to their proximity to the Tugela River and most had plots in the irrigation schemes. Garden produce of mostly maize and leafy and root vegetables contributed to food security by providing direct access to food and diversity in diets. Although questionnaire survey results showed no significant relationship between gender and growing crops, during FGDs, the women mentioned that men were generally not interested in gardening as it was considered a women's job. FGDs also revealed that although males managed the income from goats, the females managed income from the sale of garden produce. The amount of money received from 
the sale of garden produce, although small and irregular in its flow due to poor marketing, helped them purchase other goods required in the household. Results obtained a mean of ZAR300/US\$17 (1US\$= ZAR18) per household per month from the sale of garden produce.

Table 3. Relationship between the growing of crops in traditional areas and gender as a percentage

\begin{tabular}{|c|c|c|c|c|}
\hline \multirow{2}{*}{ Category } & \multicolumn{2}{|c|}{ Traditional authority area } & \multicolumn{2}{|c|}{ Gender } \\
\hline & Mchunu & Mthembu & Male & Female \\
\hline Did not grow crops & 61 & 27 & 41 & 50 \\
\hline Grew crops but did not sell & 36 & 6 & 18 & 26 \\
\hline Sold crops for $<$ ZAR500 & 3 & 22 & 17 & 4 \\
\hline Sold crops for ZAR501-1000 & 0 & 8 & 5 & 3 \\
\hline Sold crops for $>$ ZAR 1000 & 0 & 37 & 19 & 17 \\
\hline Chi-square significance & \multicolumn{2}{|c|}{$* * *$} & \multicolumn{2}{|c|}{ ns } \\
\hline
\end{tabular}

Note. Chi-square significance level: ***: $\mathrm{p}<0.01 ;$ ns: not significant.

\subsection{Household Income Level}

Male-headed households earned more income than female-headed households $(p<0.01)$ (Table 4). The main occupation of the household head caused the income differences. More male-headed households had permanent employment $(30 \%)$ than female-headed households, who mostly survived on the government old-age pension funds (33\%). Higher education levels of males enabled them to obtain permanent employment, which translated into higher incomes. On the other hand, female-headed households were mostly unemployed or depended on government old-age pensions due to lower education levels. Some unemployed household heads relied on children's social grants. FGDs revealed that the government social grant money was not adequate to buy food to last households a month, so households tended to struggle towards the month-end. Social grant money had many uses besides buying food; it paid for funeral covers, micro-lenders, stokvels and was used to buy pre-paid electricity. School feeding schemes assisted school-going children where they had one meal per day during school days. However, there was no significant difference between the total income spent on food between male and female-headed households.

Table 4. Household head occupation, total household monthly income and household income spent on food monthly, as a percentage

\begin{tabular}{lll}
\hline Category & Male-headed household (\%) & Female-headed household (\%) \\
\hline Household head occupation & & \\
Buying \& selling & 12 & 13 \\
Farming & 6 & 3 \\
Permanent job & 30 & 3 \\
Temporary job & 29 & 20 \\
Unemployed & 8 & 25 \\
Self-employed & 5 & 4 \\
Retired & 9 & 33 \\
\hline Total household monthly income & 2 & 1 \\
$<$ ZAR1000 & 65 & 93 \\
ZAR1001-5000 & 33 & 5 \\
$>$ ZAR5000 & 35 & 45 \\
\hline Household income spent on food monthly & 39 & 67 \\
$<$ ZAR1000 & 21 & 7 \\
ZAR1001-1500 & 5 & 1 \\
ZAR1501-2000 & & \\
$>$ ZAR2000 & & \\
\hline
\end{tabular}

Note. Chi-square significance level: ${ }^{* *}: \mathrm{p}<0.01 ;$ ns: not significant. 


\subsection{Use of Income From Goat Sales}

FGDs showed that goat keeping did not aid household food security because it generated little income. Goat sales were generally low, although male headed-household sold more goats (with a mean of 2.1) than female headed-households (with a mean of 1.0) in 12 months $(\mathrm{p}<0.05)$. Most farmers claimed that goat flock sizes did not increase due to mortality resulting from poor nutrition in the dry seasons, diseases (such as heartwater and coccidiosis), inadequate housing, and predation. Dogs that attacked vulnerable kids caused predation. Farmers limited goat sales when flock sizes were small, so sporadic sales were only during emergencies such as funerals and ill-health. The selling of a goat to buy food for a household occurred only when there was a 'crisis' such as extreme hunger cases when the household could not use neighbours, friends, or micro-lenders to borrow money. Farmers revealed that goats were not their main income source and a year could pass without a single goat sale. According to the farmers, if they sell goats too frequently, the small flock sizes mean that they would have nothing to fall back on when a 'real crisis' arose. Only those with larger goat flock sizes (above 50) could sell more often. Having smaller flock sizes was also seen as reflecting poverty and so most households would rather keep their goats than sell each time there is inadequate food in the household. As such, farmers revealed that some households would instead go to bed hungry than sell their goats.

\subsection{Association Between HFIAS and Socio-economic Characteristics}

The results table categorized HFIAS into four: food secure, mildly food insecure, moderately food insecure and severely food insecure to analyse the association between food security and household socio-economic characteristics (Table 5). Results showed a significant difference between male and female-headed households regarding food security, with more males than females belonging to the food secure category $(\mathrm{p}<0.05)$. There were also significant differences between food security and size of the household $(\mathrm{p}<0.05)$, marital status $(\mathrm{p}<$ $0.05)$, household head education level $(\mathrm{p}<0.05)$, household head occupation $(\mathrm{p}<0.01)$, total household income $(\mathrm{p}<0.01)$, source of regular food $(\mathrm{p}<0.01)$, number of meals per day $(\mathrm{p}<0.01)$ and location $(\mathrm{p}<0.01)$.

The larger the household size, the more they become food insecure. The higher the household head's education level, the more food secure they were, while households with little or no education levels were less food secure. However, there were no significant differences between food security and land ownership and the number of goats owned by a household. Although FGDs revealed that only farmers with larger goat flock sizes sold more goats than those with fewer, this did not translate to food security because this only applied to a few farmers. So the questionnaire survey results did not show significant differences between those with many or fewer goat flock sizes.

Household head occupation, related to education level and total income, showed that household heads with permanent employment were more food secure than unemployed, self-employed, or dependent on old age pensions and earned less income. An interview with a social worker in the study area indicated that households where the head was unemployed often dependent on the government social child grant. This social grant aimed to assist children but ended up feeding the entire household making it inadequate to meet its intended beneficiaries. As a result, meals eaten were unbalanced, inadequate or not nutritious. Households who owned gardens and produced some of their household food were more food secure than those dependent on having income to purchase food from the supermarkets. The number of meals eaten per day also affected food security. Results showed that the fewer the number of meals eaten, the fewer households were food secure. Mthembu traditional authority area was more food secure when compared to Mchunu. FGDs in Mchunu mentioned that in contrast to Mthembu, their area did not have water to allow them to have gardens and so they were forced to buy all the food they require, which is a challenge due to lack of purchasing power. 
Table 5. Food security and household parameters

\begin{tabular}{|c|c|c|c|c|c|c|}
\hline \multirow[b]{2}{*}{ Variable } & \multirow[b]{2}{*}{ Category } & \multicolumn{4}{|c|}{ Food security status } & \multirow{2}{*}{$\begin{array}{l}-X^{2} \text { significance } \\
\text { level }\end{array}$} \\
\hline & & Food secure & $\begin{array}{l}\text { Mildly food } \\
\text { insecure }\end{array}$ & $\begin{array}{l}\text { Moderately food } \\
\text { insecure }\end{array}$ & $\begin{array}{l}\text { Severely food } \\
\text { insecure }\end{array}$ & \\
\hline \multirow{2}{*}{ Household head gender } & Male & 18 & 120 & 9 & 18 & $* *$ \\
\hline & Female & 8 & 38 & 12 & 18 & \\
\hline \multirow{2}{*}{ Location } & Mchunu & 13 & 57 & 16 & 32 & $* * *$ \\
\hline & Mthembu & 13 & 101 & 5 & 4 & \\
\hline & Single & 2 & 4 & 2 & 3 & ${ }^{*--}$ \\
\hline \multirow{3}{*}{ Household head marital status } & Married & 15 & 96 & 7 & 16 & \\
\hline & Widowed & 6 & 31 & 9 & 16 & \\
\hline & Cohabiting & 3 & 27 & 3 & 1 & \\
\hline \multirow{4}{*}{ Household head education level } & None & 4 & 34 & 10 & 15 & $* *$ \\
\hline & Primary & 9 & 67 & 9 & 15 & \\
\hline & Secondary & 8 & 48 & 2 & 5 & \\
\hline & Tertiary & 5 & 9 & 0 & 1 & \\
\hline \multirow{3}{*}{ Land ownership } & Allocated & 24 & 156 & 19 & 35 & ns \\
\hline & Inherited & 1 & 1 & 1 & 0 & \\
\hline & Bought & 1 & 1 & 1 & 1 & \\
\hline \multirow{7}{*}{ Household head occupation } & Buying \& selling & 3 & 19 & 6 & 2 & $* * *$ \\
\hline & Farming & 0 & 11 & 1 & 0 & \\
\hline & Permanent job & 11 & 38 & 0 & 3 & \\
\hline & Temporary job & 1 & 49 & 5 & 8 & \\
\hline & Unemployed & 2 & 13 & 7 & 10 & \\
\hline & Self employed & 1 & 9 & 0 & 2 & \\
\hline & Retired & 8 & 19 & 2 & 11 & \\
\hline \multirow{2}{*}{ Source of regular meal } & Supermarkets & 19 & 60 & 13 & 30 & $* * *$ \\
\hline & Own production \& supermarkets & 7 & 98 & 8 & 6 & \\
\hline \multirow{3}{*}{ Total household size } & $<5$ & 10 & 31 & 5 & 16 & $* *$ \\
\hline & $6-10$ & 10 & 76 & 11 & 15 & \\
\hline & $>10$ & 6 & 51 & 5 & 5 & \\
\hline & $<25$ & 21 & 90 & 14 & 30 & ns \\
\hline \multirow[t]{3}{*}{ No. of goats per household } & $26-50$ & 5 & 61 & 7 & 4 & \\
\hline & $>50$ & 0 & 7 & 0 & 2 & \\
\hline & 3 & 25 & 113 & 8 & 13 & $* * *$ \\
\hline \multirow[t]{3}{*}{ No. of meals per day } & 2 & 1 & 43 & 13 & 21 & \\
\hline & 1 & 0 & 2 & 0 & 2 & \\
\hline & $<$ ZAR1000 & 0 & 0 & 0 & 5 & $* * *$ \\
\hline \multirow[t]{2}{*}{ Total household income } & ZAR1001-5000 & 14 & 115 & 20 & 29 & \\
\hline & $>$ ZAR5000 & 12 & 43 & 1 & 2 & \\
\hline
\end{tabular}

Note. $* * *$ is significant at $\mathrm{p}<0.01 ; * *$ is significant at $\mathrm{p}<0.05$; ns is not significant.

\subsection{Determinants of Food Security}

The results in Table 6 indicate that seven estimated coefficients were statistically significant. The relationship between gender and food security was statistically significant. The positive coefficient indicates that female-headed households were worse off than males in terms of food security. There was a statistically significant negative coefficient for saving money, indicating that households that save money were more food secure than those which did not. There was a statistically significant negative coefficient for location, indicating that the Mthembu traditional authority area was more food secure than Mchunu traditional authority area. The difference in food security emanated from Mthembu farmers having access to gardens. There was a statistically significant negative coefficient for total household income. The negative coefficient indicates that households with more income are more food secure.

Although there was a statistically significant coefficient for food storage, the positive coefficient indicates that households that store food are less food secure than their counterparts. A possible reason could be that households that store food might not have had a continuous income flow and were less food insecure. There was a statistically significant negative coefficient for goat sales in the past 12 months indicating that households that sold goats had the income to buy food, making them more secure. Goat flock size had a statistically significant 
positive coefficient. This coefficient indicates that goat ownership meant food insecurity, which is contrary to expectations. A plausible explanation for this could be that larger goat flock sizes distracted households' economic activities, making households more food insecure than their counterparts. Households with larger flock sizes might be more attached to them and unwilling to convert them to food to make them food secure.

In the Tobit model, the reciprocal of the tolerance value, which measures the influence of collinearity among variables (VIF), was below the acceptable cut-off value of 10 (Hair et al., 2014), meaning that there was a low correlation among variables since the VIFs were in acceptable ranges.

Table 6. Tobit estimates of the determinants of food security

\begin{tabular}{|c|c|c|c|c|}
\hline Variable & Coefficient & Standard Error & $\mathrm{P}>|\mathrm{t}|$ & VIF \\
\hline Gender & $2.220 * *$ & 0.672 & 0.001 & 1.39 \\
\hline Education level & -0.509 & 0.372 & 0.172 & 1.49 \\
\hline Location & $-1.367 *$ & 0.644 & 0.035 & 1.46 \\
\hline Sold goats in 12 months & $-0.514^{*}$ & 0.311 & 0.099 & 1.30 \\
\hline Saved money & $-1.179 *$ & 0.553 & 0.034 & 1.59 \\
\hline Household head age & 0.459 & 0.536 & 0.392 & 1.18 \\
\hline Food storage & $1.121^{*}$ & 0.572 & 0.051 & 1.11 \\
\hline Number of goats & $0.051^{*}$ & 0.024 & 0.032 & 1.47 \\
\hline Total household income & $-1.941 * *$ & 0.698 & 0.006 & 1.46 \\
\hline _constant & 9.847 & 1.902 & 0.000 & \\
\hline Var (HFAIS) & 16.534 & 1.629 & & \\
\hline \multicolumn{5}{|l|}{$\begin{array}{l}\text { Limits: lower }=0 \\
\text { upper }=27\end{array}$} \\
\hline \multicolumn{5}{|l|}{ No. of obs. $=241$} \\
\hline \multicolumn{5}{|l|}{ Uncensored $=230$} \\
\hline \multicolumn{5}{|l|}{ Left-censored $=11$} \\
\hline \multicolumn{5}{|l|}{ Right-censored $=0$} \\
\hline \multicolumn{5}{|l|}{ Wald $\operatorname{chi}^{2}(9)=77.91$} \\
\hline \multicolumn{5}{|l|}{ Prob $>$ chi $^{2}=0.000$} \\
\hline \multicolumn{5}{|l|}{ Log likelihood $=-632.229$} \\
\hline Pseudo $\mathrm{R}^{2}=0.058$ & & & & \\
\hline
\end{tabular}

\section{Discussion}

The socio-economic factors that influenced food security were location, marital status, regular meal source, total household size, gender, education level, occupation, total household income, and meals per day. Baiphethi and Jacobs (2009), Shisanya and Hendriks (2011), and Selepe et al. (2015) mentioned that home gardens positively contribute towards food security. Gardens decrease micro-nutrient deficiencies and allow households to buy the foods they do not produce, increasing financial savings on food bills. The effects of gardens on food security manifested themselves in Mthembu traditional area where residents were involved in gardening and were more food secure than Mchunu residents. Water is a basic need and key to household food security through food preparation, processing and production (Selepe et al., 2015). Mchunu residents had underutilized land not used for crop production or gardening due to lack of water, and this contributed to them being food insecure as they only relied on supermarkets to obtain food. Obtaining food from supermarkets requires purchasing power that households often do not have, and so households that grew their crops had more likelihood of attaining food security. Garden produce such as maize and leafy, and root vegetables were used mostly for household consumption, with sales being small and irregular in its flow due to poor marketing. Household earned mean of ZAR300/US\$17 (1US\$ = ZAR18) per household per month from the sale of garden produce. Although inadequate to sustain Mthembu households, the garden produce helped them become more food secure than those in the Mchunu tribal area because it provided direct access to food and diversity in diets, while the money helped them purchase other goods required in the household. Mrema and Chitiyo (2011) reported that vegetable home gardening is one of the agri-based safety nets against food shortages and nutritional needs. Patel and Hochfeld (2011) and Murugani et al. (2014), in their studies, mentioned that women in agriculture need to be supported by government authorities to curb food insecurity in households. In addition, Maziya et al. (2017) 
conducted studies in the same study area of Msinga recommended that infrastructure investments for irrigation farming and a high level of competence in fertilizer application can enhance food security.

Meyer and Nishimwe-Niyimbanira (2016) and Oyekale (2013) indicated an unclear relationship between poverty and household size. Households with more children may have more labour to work on the land with the hope of increasing income. On the contrary, large households with many dependents are likely to be poor and hence food insecure because they require large income to keep the family members out of poverty and provide daily meals. A study showed that larger household sizes were more food insecure than those with smaller sizes.

Results showed that the number of meals consumed per day affected food security. Food insecurity resulted from insufficient meals eaten per day, while food security was seen in households that could afford more meals per day. Manjengwa (2012) reported that poor households may consume food of poor nutritional quality or fewer meals per day because they cannot afford more meals. Such households may be food insecure because of an insufficient number of meals eaten per day. The more meals eaten per day means more food is eaten, so households that can afford more meals per day tend to be more food secure.

The marital status of the household had a significant relationship with food security, with the single and widowed being less food secure. In their study, Selepe et al. (2015) found that single-headed households led by women were food insecure because they did not have stable employment to provide sufficient and nutritious food for their household. Coping strategies mentioned in the study were in line with those stated by D'Souza and Jollifffe (2012) and Mkhawani et al. (2016) that households may resort to selling livestock, borrow money to buy food and reduce spending on food in the face of emergencies.

At the household level, the determinants of food security were total household income, gender, education levels, saving money, location with access to irrigation to sustain gardens and sale of goats in the previous 12 months. Food security was lower amongst households with little or no education, the unemployed and those receiving little household income. This is because more income enables a household to secure food through purchasing. Obi and Tafa (2016) alluded to the fact that there is a strong correlation between poverty and unemployment. Baiyegunhi and Fraser (2010) stated that households are more vulnerable to poverty and food insecurity when their head's education level is low. The more the household head spent in school, the more their chances of finding a better paying job, which increases household food security. Higher education levels may have had the combined effect of better nutrition and better access to food due to higher incomes, as De Cock et al. (2013) stated. Similarly, Gebre (2012) noted that education significantly correlates with food security.

Some authors presented arguments on the head of household's age and stated that food insecurity and poverty were prevalent in households whose heads are younger due to the youth's reliance on adults for food provision as argued by Obi and Tafa (2016). On the contrary, Baiyegunhi and Fraser (2010) argued that households headed by old age people could be more vulnerable because they cannot fend for themselves due to their old age. In the current study, age of household head did not influence food security.

Saving money was also a determinant of food security in the study. Where households had money kept for future use were positioned to prevent shocks such as drought, income insecurity, and increasing food prices. Although Gitonga et al. (2013) explained that food storage is of great importance to food security because it bridges the gap between two harvests and stabilizes prices by taking the produce off the market during the peak season; in the current study, storing food did not contribute to food security. A possible reason is that households that store food might not have a continuous income flow and are less food insecure. The study did not measure the quantity and type of food stored, and so the quantity or type of food stored by households might not have contributed to food security. The period of storage, of 30 days, might not have been long enough to have any impact on households' food security adequately.

There was a significant relationship between food security and the gender of the household head. Female-headed households were less food secure than male-headed households. Baiyegunhi and Fraser (2010) obtained similar results that food insecurity and poverty are more likely to be higher in female-headed households than male-headed households. This is because females often did not have reliable employment to provide adequate and nutritious food for their households.

FGDs findings align with those from the questionnaire survey that goat farming did not contribute to household food security. Although FGDs revealed that farmers with larger goat flock sizes sold more goats than their counterparts and used the income to buy food. The study may not conclude that the food security situation increases through goat sales because only a few farmers had large flock sizes. FGDs results mentioned that for most farmers, there was little income obtained from goat sales. For most households, goat flock numbers did not increase effectively due to diseases, poor nutrition, theft, and predation. Where the goat flock size was small, 
households limited goat sales to maintain the potential to increase their flock size. Hence, there were only sporadic sales, particularly when there were household emergencies such as funerals and ill-health. This corresponds with Byaruhanga et al. (2014)'s findings that households with larger flock sizes sold significantly more goats than those with smaller flock sizes. Negassa and Jabbar (2014) also mentioned that flock size positively correlated with a household's choice of participation in goat sales, with goat sales restricted where flock sizes were small. The household food basket cost ZAR3 400/US\$188 (Economic Justice and Dignity Group, 2020). FGDs reported that the cost of the sale of a single goat was said to be on average ZAR1000/US\$56. Therefore, a household would need to sell up to four goats each month to survive solely on goat farming, which translates to up to 48 goats per year. As a result, goat farming did not translate to food security for most households due to small goat flock sizes, and their sales realized little income. The study had hypothesized that addressing food insecurity requires assets such as goats can be living savings and converted into cash to buy food for the household whenever needed. Therefore, the hypothesis gets rejected in the current study since goat farming was found not to contribute to household food security because it generated little income as goat sales were generally low.

\section{Conclusions}

This study collected information on household composition, food consumption, food production, household income, and ownership of goats and their relation to food security. The results showed that the determinants of food security at the household level were education levels, the total household income, gender, saving money, sale of goats in the previous 12 months, and a location with access to irrigation to sustain gardens. Female-headed households were less food secure than male-headed households. Empowering women is, therefore, crucial to ensuring food security. Unstable employment opportunities lead households to be unable to cope with food insecurity adequately. Hence, promoting rural education may significantly improve food security levels, as education significantly correlates with food security. Improving goat production is important if flock sizes are to increase.

Increasing goat flock numbers will enable farmers to make more sales, leading to the improvement of food security. The study also found gender disparities in goat ownership and the decision-making process between male and female-headed households. This was attributed to females' cultural set-up and low literacy levels, resulting in females being less empowered to achieve gender equality within households. Increasing literacy levels of females will also increase their chances of being more exposed to better management options, acquiring a better understanding of goat management practices, and making informed decisions. Therefore, compared to men, women do not reach their full potential in the agriculture sector due to low literacy levels, limited resources and participation in decision-making. This is due to cultural settings that allow men to own goats in households and decide to sell. Policies should focus on promoting education, especially among women, and creating an enabling environment for the rural labour market. Provision of appropriate policies that can raise household incomes and rural wages and improve rural economies are needed. This may entail mobilizing households through education and training to be entrepreneurs and creating their opportunities is important since the chance of employment is scarce. There is also a need to reduce rural households' autonomy and dependency on supermarket goods and make them more agri-oriented. Agricultural development programmes need to incorporate gender and goat farming to design, implement, and evaluate intervention programmes on improving food security. Extension workers in the study area of Msinga need to help farmers to manage and utilize their goats better in order for goat farming to reach its full potential. This may be done by assisting goat farmers in improving goat nutrition, health and management. However, care should be taken not to lead to a land degradation problem caused by the increasing number of goats. Further sustainable goat production methods research is needed, e.g., on the use of drought-tolerant fodder.

\section{Acknowledgments}

The authors would like to thank the Farmer Support Group of the University of KwaZulu-Natal for providing financial support. In addition, they would like to thank the community of Msinga for their voluntary participation in the study. Lastly, the authors would like to acknowledge each other's contributions: Tsvuura S for conceptualization, investigation, data curation, and original draft preparation of the manuscript; Mudhara $\mathrm{M}$ and Chimonyo $\mathrm{M}$ for provision of resources, supervision; and review and editing of the manuscript.

\section{References}

Abdullaha, Zhou, D., Shah, T., Ali, S., Ahmad, W., Ud Din, I., \& Ilyas, A. (2017). Factors affecting household food security in rural northern hinterland of Pakistan. Journal of the Saudi Society of Agricultural Sciences, 18(2), 201-210. https://doi.org/10.1016/j.jssas.2017.05.003 
Adams-Kane, J., \& Lim, J. J. (2016). Institutional quality mediates the effect of human capital on economic performance. Review of Development Economics, 20, 426-442. https://doi.org/10.1111/rode.12236

Aldosari, F. O. (2017). Gender participation in sheep and goat farming in Najran, southern Saudi Arabia. Saudi Journal of Biological Sciences, 25, 144-148. https://doi.org/10.1016/j.sjbs.2017.03.013

Ansah, I. G. K., Gardebroek, C., \& Ihle, R. (2019). Resilience and household food security: A review of concepts, methodological approaches and empirical evidence. Food Security, 11, 1187-1203. https://oi.org/10.1007/ s12571-019-00968-1

Babajide, A. A. A. (2015). Livestock ownership by gender and seasonal impact on production: A case study in Msinga Municipality (Masters thesis, University of KwaZulu-Natal, Pietermaritzburg, South Africa).

Bahta, S., Wanyoike, F., Katjiuongua, H., \& Marumo, D. (2017). Characterization of food security and consumption patterns among smallholder livestock farmers in Botswana. Agriculture and Food Security, 6(65), 1-11. https://doi.org/10.1186/s40066-017-0145-1

Baiphethi, M., \& Jacobs, P. J. (2009). The contribution of subsistence farming to food security in South Africa. Agrekon, 4(48), 459-482. https://doi.org/10.1080/03031853.2009.9523836

Baiyegunhi, L. J. S., \& Fraser, G. C. (2010). Determinants of household poverty dynamics in rural regions of the Eastern Cape Province, South Africa. In poster presented at the Joint 3rd African Association of Agricultural Economists (AAAE) and 48th Agricultural Economists Association of South Africa (AEASA) Conference, Cape Town, South Africa. Retrieved March 9, 2019, from http://ageconsearch.umn.edu/ bitstream/97078/2/63.\%20Poverty\%20dynamics\%20in\%20South\%20Africa.pdf

Banwat, M. E., Lar, L. A., Dakum, L. B., Igoh, C. S., Daboer, J. C., \& Ogbonna, C. (2012). Factors affecting household food security in a rural community in North-Central Nigeria. International Journal of Community Research, 1(1), 23-29.

Barrett, C. B., Reardon, T., \& Webb, P. (2001). Nonfarm income diversification and household livelihood strategies in rural Africa: Concepts, dynamics, and policy implications. Food Policy, 26(4), 315-331. https://doi.org/10.1016/S0306-9192(01)00014-8

Bettencourt, E. M. V., Tilman, M., Narciso, V., da Silva Carvalho, M. L., \& de Sousa Henriques, P. D. (2015). The Livestock Roles in the Wellbeing of Rural Communities of Timor-Leste. Revista de Economia e Sociologia Rural, 53(1), 63-80. https://doi.org/10.1590/1234-56781806-94790053s01005

Brinkman, H. J., Saskia, D. P., Ludovic, S., \& Martin, W. (2010). High food prices and the global financial crisis have reduced access to nutritious food and worsened nutritional status and health. The Journal of Nutrition, 140, 153-161. https://doi.org/10.3945/jn.109.110767

Brody, A. (2015). Gender and Food Security: Towards Gender-Just Food and Nutrition Security-Overview Report. Brighton, UK, BRIDGE Cutting Edge Programmes.

Byaruhanga, C., Oluka, J., \& Olinga, S. (2014). Socio-economic aspects of goat farming enterprise in Teso region, Uganda. Uganda Journal of Agricultural Sciences, 15(1), 87-100.

Chukwuka, O. K., Okoli, I. C., Okkeudo, N. J., Opara, M. N., Hebert, U., Ogbuewu, I. P., \& Ekenyem, B. U. (2010). Reproductive potentials of West African Dwarf sheep and goats: A review. Research Journal of Veterinary Sciences, 3, 86-100. https://doi.org/10.3923/rjvs.2010.86.100

Coates, J., Swindale, A., \& Bilinsky, P. (2007). Household Food Insecurity Access Scale (HFIAS) for Measurement of Household Food Access: Indicator Guide (Vol. 3). Food and Nutrition Technical Assistance Project (FANTA), Academy for Educational Development, Washington, DC. https://doi.org/ 10.1037/e576842013-001

Cousins, B. (2012). Smallholder irrigation schemes, agrarian reform and accumulation from below: Evidence from Tugela Ferry, KwaZulu-Natal. Paper for a conference on strategies to overcome poverty and inequality: Towards Carnegie III, September 3-7, 2012, University of Cape Town, South Africa.

Cunillera, O. (2014). Tobit Models. Encyclopedia of Life and Well-being Research, 6671-6676. https://doi.org/ 10.1007/978-94-007-0753-5_3025

D’Souza, A., \& Jolliffe, D. (2012). Rising Food Prices and Coping Strategies: Household-level Evidence from Afghanistan. Journal of Development Studies, 48(2), 282-299. https://doi.org/10.1080/00220388.2011. 635422 
Daniel, M., Coates, J., \& Vaitla, B. (2013). How Do Different Indicators of Household Food Security Compare? Empirical Evidence from Tigray. Feinstein International Center, Tufts University: Medford, USA.

De Cock, N., D’Haese, M., Vink, N., van Rooyen, C. J., Staelens L., Schönfeldt, H. C., \& D’Haese, L. (2013). Food security in rural areas of Limpopo province, South Africa. Food Security, 5, 269-282. https://doi.org/ 10.1007/s12571-013-0247-y

Dearlove, P. D. (2007). Msinga municipality integrated development plan 2005/2006. Pietermaritzburg: KwaZulu-Natal Department of Local Governance and Traditional Affairs.

Deere, C. D., Alvarado, G., \& Twyman, J. (2012). Gender inequality and asset ownership in Latin America: Female owners vs household heads. Development and Change, 43(2), 505-530. https://doi.org/10.1111/ j.1467-7660.2012.01764.x

Desta, H., Kinat, W., Alemu, B., Mulema, A., Van Eerdewijk, A., \& Wieland, B. (2017). Small ruminant production for food security 'Goats are cattle gifted for the poor'. CGIAR, Addis Ababa.

Doss, C. (2013). Data needs for gender analysis in agriculture (Discussion Paper 01261). IFPRI, Washington, DC. https://doi.org/10.1007/978-94-017-8616-4_3

Dube, K. (2015). Characterisation of goat production systems in selected coastal areas of the Eastern Cape Province, South Africa (Masters degree Thesis, University of Fort Hare, Alice).

Duflo, E. (2003). Grandmothers and granddaughters: Old-age pensions and intra-household allocation in South Africa.World Bank Economic Review, 17(1), 1-25. https://doi.org/10.1093/wber/lhg013

Durlauf, S. N., \& Blume, L. E. (2010). Microeconometrics. Macmillan Publishers Ltd., London. https://doi.org/ $10.1057 / 9780230280816$

Economic Justice and Dignity Group. (2020). Food prices, social grants and Covid-19. Pietermaritzburg, South Africa.

FAO (Food and Agriculture Organization). (2008). Deriving Food Security Information from National Household Budget Surveys: Experiences, Achievements, Challenges. Food and Agricultural Organization of the United Nations, Rome.

FAO (Food and Agriculture Organization). (2015b). The State of Food Insecurity in the World 2015. Retrieved March 2, 2018, from https://www.fao.org

FAO (Food and Agriculture Organization). (2016). Report on World Food Summit. World Food Summit, WFS 96/REP Part One, Rome.

FAO (Food and Agriculture Organization). (2017). Food security, sustaining peace and gender equality: Conceptual framework and future directions. SP5 Discussion Paper. Retrieved from https://www.fao.org

FAO (Food and Agriculture Organization)/ADB (Asian Development Bank). (2013). Gender Equality and Food Security: Women's Empowerment as a Tool against Hunger. Mandaluyong City, Philippines, ADB.

Faridi, R., \& Wadood, S. (2010). An econometric assessment of household food security in Bangladesh. Bangladesh Development Studies, 33(3), 97-111.

Felker-Kantor, E., \& Wood, C. H. (2012). Female headed households and food insecurity in Brazil. Food Security, 4(4), 607-617. https://doi.org/10.1007/s12571-012-0215-y

GAP KZN (Goat Agribusiness Project of KwaZulu Natal). (2017). GAP Umzinyathi District 2016-2017 census. Retrieved March 9, 2019, from https://www.gapkzn.co.za/Umzinyathi.php

García-Winder, M., \& Chavarría, H. (2017). The Outlook for Agriculture and Rural Development in the Americas: A Perspective on Latin America and the Caribbean 2017-2018/ECLAC, FAO, IICA. San Jose, Costa Rica.

Gitonga, Z. M., Groote, H. D., Kassie, M., \& Tefera, T. (2013). Impact of metal silos on households' maize storage, storage losses and food security. Journal of Food Policy, 43, 44-55. https://doi.org/10.1016/ j.foodpol.2013.08.005

Gubbels, P. (2013). Changing the Development Paradigm: Key to Managing Drought Risk in areas of Chronic Food Insecurity in Africa. Background Paper prepared for the Global Assessment Report on Disaster Risk Reduction. Retrieved March 9, 2019, from https://www.preventionweb.net/english/hyogo/gar/../Gubbels,\% 202012.pdf 
Hair, J. F., Black, W. C., Babin, B. J., \& Anderson, R. E. (2014). Multivariate Data Analysis (7th ed.). Pearson New International Edition, Essex.

Hassen, A. S., \& Tesfaye, Y. (2014). Sheep and goat production objectives in pastoral and agro-pastoral production systems in Chifra district of Afar, Ethiopia. Tropical Animal Health and Production, 46, 1467-1474. https://doi.org/10.1007/s11250-014-0668-4

Hoddinot, J. F., \& Yohannes, Y. (2002). Dietary diversity as a food security indicator (Discussion Paper 136). Food Consumption and Nutrition Division of the IFPRI.

Hulela, K. (2010). The role of women in sheep and goats production. International Journal of Scientific Research in Education, 3(3), 177-187.

Ibnouf, F. O. (2011). Challenges and possibilities for achieving household food security in the Western Sudan region: The role of female farmers. Food Security, 3(2), 215-231. https://doi.org/10.1007/s12571-011-0118-3

Johnson, N. L., Kovarik, C., Meinzen-Dick, R., Njuki, J., \& Quisumbing, A. (2016). Gender, assets and agricultural development: Lessons from eight projects. World Development, 83, 295-311. https://doi.org/ 10.1016/j.worlddev.2016.01.009

Kassie, M., Ndiritu, S. W., \& Stage, J. (2014). What determines gender inequality in household food security in Kenya? Application of exogenous switching treatment regression. World Development, 56, $153-171$. https://doi.org/10.1016/j.worlddev.2013.10.025

Lê, Q., Auckland, S., Nguyen, H. B., Murray, S., Long, G., \& Terry, D. R. (2015). The Socio-Economic and Physical Contributors to Food Insecurity in a Rural Community. SAGE Open, 1, 1-21. https://doi.org/ $10.1177 / 2158244014567401$

Mallick, D., \& Rafi, M. (2010). Are female-headed households more food secure? Evidence from Bangladesh. Journal of World Development, 38(4), 593-605. https://doi.org/10.1016/j.worlddev.2009.11.004

Mango, N., Zamasiya, B., Makate, C., Nyikahadzoi, K., \& Siziba, S. (2014). Factors influencing household food security among smallholder farmers in the Mudzi district of Zimbabwe. Development Southern Africa, 31(4), 625-640. https://doi.org/10.1080/0376835X.2014.911694

Manjengwa, J., Feresu, S., \& Chimhowu, A. (2012). Understanding poverty, promoting wellbeing and sustainable development. A sample survey of 16 districts of Zimbabwe Institute of Environmental Studies, Computer Science Building, University of Zimbabwe, Harare.

Manyamba, C., Hendriks, S. L., Chilonda, P., \& Musaba, E. (2012). Factors Contributing to Inequalities in Food Security in South Africa: Implications for Agricultural Policy. Strategies to overcome poverty and inequality. 'Towards Carnegie 111' Conference University of Cape Town September 3-7, 2012.

Mathebula, J., Molokomme, M., Jonas, S., \& Nhemachena, C. (2017). Estimation of household income diversification in South Africa: A case study of three provinces. South African Journal of Science, 113(1/2), 1-9. https://doi.org/10.17159/sajs.2017/20160073

Maziya, M., Mudhara, M., \& Chitja, J. (2017). What factors determine household food security among smallholder farmers? Insights from Msinga, KwaZulu-Natal, South Africa. Agrekon, 56(1), 40-52. https://doi.org/10.1080/03031853.2017.1283240

McDonald, J. F., \& Moffitt, R. A. (1980). The Uses of Tobit Analysis. The Review of Economics and Statistics, 62(2), 318-321. https://doi.org/10.2307/1924766

Meyer, D. F., \& Nishimwe-Niyimbanira, R. (2016). The impact of household size on poverty: An analysis of various low-income townships in the Northern Free State region, South Africa. African Population Studies, 30(2), 2283-2295. https://doi.org/10.11564/30-2-811

Mkhawani, K., Motadi, S. A., Mabapa, N. S., Mbhenyane, X. G., \& Blaauw, R. (2016). Effects of rising food prices on household food security on female headed households in Runnymede Village, Mopani District, South Africa. South African Journal of Clinical Nutrition, 29(2), 69-74. https://doi.org/10.1080/16070658. 2016.1216504

Mokwena, M. N. A. P. (2016). Impact of social grant on food security: Evidence from neighbourhoods in the Gauteng Province of South Africa (PhD Thesis, North-West University, Vaal Triangle Campus). 
Mrema, M., \& Chitiyo, F. (2011). Home Gardening as a Coping Strategy for Urban and Peri-Urban Households: The Case of Mutare City, Manicaland Province, Zimbabwe, during the 2008 Hyperinflation Period. Department of Agribusiness, Faculty of Agriculture and Natural Resources, Africa University, Zimbabwe.

Msinga Municipality IDP. (2014). About Msinga. Retrieved October 13, 2018, from http://www.msinga.org/ index.php/about-us

Muche, M., Endalew, B., \& Koricho, T. (2014). The determinants of household food security among south west Ethiopian rural households. Asian Journal of Agricultural Research, 8, 248-258. https://doi.org/10.3923/ ajar.2014.248.258

Muhoyi, E., Mukura, T. J., Ndedzu, D., Makova, T., \& Munamati, O. (2014). Determinants of household food security in Murehwa district. Journal of Economics and Sustainable Development, 5(3), 84-92.

Murugani, V. G., Thamaga-Chitja, J. M., Kolanisi, U., \& Shimelis, H. (2014). The Role of Property Rights on Rural Women's Land Use Security and Household Food Security for Improved Livelihood in Limpopo Province. Journal of Human Ecology, 46(2), 205-221. https://doi.org/10.1080/09709274.2014.11906721

Ngambi, J. W., Alabi, O. J., \& Norris, D. (2013). Role of goats in food security, poverty alleviation and prosperity with special reference to Sub-Saharan Africa: A review. Indian Journal of Animal Research, 47, $1-9$.

Njuki, J., \& Sanginga, P. (2013). Women, livestock ownership and markets: Bridging the gender gap in Eastern and Southern Africa. Abingdon, United Kingdom, Routledge. https://doi.org/10.4324/9780203083604

Nussbaum, M. C. (2011). Creating capabilities: The human development approach. MA: Harvard University Press, Cambridge. https://doi.org/10.4159/harvard.9780674061200

Nyako, A. M. (2013). The relationship between educational attainment and food security in Nigeria (Unpublished thesis, Faculty of the Graduate School of Arts and Sciences, Georgetown University, Washington DC).

Obi, A., \& Tafa, S. (2016). The determinants of household poverty in South Africa. South Africa's Public Service Delivery and Performance Review, 4(4), 516-538. https://doi.org/10.4102/apsdpr.v4i4.137

Olowu, D. (2013). Gendered Aspects of Food Security in Lesotho: Implications for an Integrative Rights-Based Approach. Gender and Behaviour, 11(2), 5378-5392.

Oyekale, A. S. (2013). Gender Role in Agriculture, Climate Change and Food Security in the Sahel Belt of West Africa: Application of Poisson and Negative Binomial Regression. Gender and Behaviour, 11(2), 5499-5511.

Patel, L. (2012). Poverty, gender and social grants in Soweto, South Africa. Policy, Design and Practice, 1-2, 106-120. https://doi.org/10.1080/15588742.2012.625344

Patel, L., \& Hochfeld, T. (2011). It buys food but does it change gender relations? Child Support Grants in Soweto, South Africa. Gender and Development, 19(2), 229-240. https://doi.org/10.1080/13552074.2011. 592633

Patel, L., Knijn, T., \& Van Wel, F. (2015). Child support grants in South Africa: A pathway to women's empowerment and child well-being? Journal of Social Policy, 44(2), 377-397. https://doi.org/10.1017/ S0047279414000919

Pérez-Escamilla, R., Gubert, M. B., Rogers, B., \& Hromi-Fiedler, A. (2017). Food security measurement and governance: Assessment of the usefulness of diverse food insecurity indicators for policy makers. Global Food Security, 14, 96-104. https://doi.org/10.1016/j.gfs.2017.06.003

Rahman, M., Hossain, M., \& Miah, M. (2016). Poverty reduction and livelihood improvement of women through goat rearing. Asian Journal for Poverty Studies, 3(1), 59-66.

Raosoft. (2004). Sample Size Calculator, Inc. Retrieved March 9, 2019, from http://www.raosoft.com/ samplesize.html

Rose, D. D. (2008). Interventions to reduce household food insecurity: A synthesis of current concepts and approaches for Latin America. School of Public Health and Tropical Medicine, Department of Community Health Sciences, Tulane University, New Orleans. https://doi.org/10.1590/S1415-52732008000500014 
Ruel, M.T. (2002). Is dietary diversity an indicator of food security or dietary quality? A review of measurement issues and research needs. Food Consumption and Nutrition Division, International Food Policy Research Institute, Washington. https://doi.org/10.1177/156482650302400217

Schwabe, C. (2004). Fact sheet: Poverty in South Africa (Fact Sheet No. 1). Human Sciences Research Council, Pretoria.

Selepe, B. M., Mtyingizane, S. S., \& Masuku, M. M. (2015). Factors contributing to household food insecurity in Mhlontlo area, Eastern Cape, South Africa. African Journal of Hospitality, Tourism and Leisure, 4(1).

Sen, A. (1999). Development as freedom. Oxford University Press, New York.

Sharaunga, S., Mudhara, M., \& Bogale, A. (2015). The Impact of 'Women's Empowerment in Agriculture' on Household Vulnerability to Food Insecurity in the KwaZulu-Natal Province. Forum for Development Studies, 42(2), 195-223. https://doi.org/10.1080/08039410.2014.997792

Shariff, Z. M., \& Khor, G. L. (2008). Household food insecurity and coping strategies in a poor rural community in Malaysia. Nutrition Research and Practice, 2(1), 26-34. https://doi.org/10.4162/nrp.2008.2.1.26

Shisanya, S. O., \& Hendriks, S. L. (2011). The contribution of community gardens to food security in the Maphephetheni uplands. Development Southern Africa, 28(4), 509-526. https://doi.org/10.1080/0376835X. 2011.605568

Statistics South Africa. (2016). Community Survey 2016. Statistical release P0301/Statistics South Africa, Pretoria.

Swindale, A., \& Bilinsky, P. (2006). Household Dietary Diversity Score (HDDS) for Measurement of Household. Food Access Indicator Guide V 2. FANTA, Washington, DC.

Tapela, B. (2011). Msinga smallholder irrigation farmers: Commercially successful smallholders using mixed technologies. Institute for Poverty, Land and Agrarian Studies, University of the Western Cape.

Thamaga-Chitja, J. M., Hendriks, S. L., Ortmann, G. F., \& Green, M. (2004). Impact of maize storage on rural household food security in Northern KwaZulu-Natal. Journal of Family Ecology and Consumer Sciences, 32, 8-15. https://doi.org/10.4314/jfecs.v32i1.52843

Trefry, A., Parkins, J., \& Cundill, G. (2014). Culture and food security: A case study of homestead food production in South Africa. Food Security, 6, 555-565. https://doi.org/10.1007/s12571-014-0362-4

Vaitla, B., Tesfay, G., Rounseville, M., \& Maxwell, D. (2012). Resilience and livelihood change in Tigray, Ethiopia. Somerville: Tufts University, Feinstein International Centre.

Verbeek, M. (2014). A Guide to Modern Econometrics. Applied Econometrics, 8, 125-132.

Watuleke, J. (2014). From sustainable development: The role of food banks in food security in Uganda: A case study of the hunger project food bank-Mbale Epicenter (Masters thesis, University of Agder, Kristiansand, Norway).

Webb, E. C., \& Mamabolo, M. J. (2004). Production and reproduction characteristics of South African indigenous goats in communal farming systems. South African Journal of Animal Sciences, 34(SP1), 236-239.

Zakari, S., Ying, L., \& Song, B. (2014). Factors Influencing Household Food Security in West Africa: The Case of Southern Niger. Sustainability, 6, 1191-1202. https://doi.org/10.3390/su6031191

\section{Copyrights}

Copyright for this article is retained by the author(s), with first publication rights granted to the journal.

This is an open-access article distributed under the terms and conditions of the Creative Commons Attribution license (http://creativecommons.org/licenses/by/4.0/). 